University of Nebraska - Lincoln

DigitalCommons@University of Nebraska - Lincoln

Faculty Publications from the Harold W. Manter Laboratory of Parasitology

4-1975

Histochemistry of the Tissue Capsule Surrounding Intradermal Mites, Hannemania spp. (Acarina: Trombiculidae) in New Mexico Amphibians

\author{
Jill J. Grover \\ University of New Mexico \\ Donald W. Duszynski \\ University of New Mexico, eimeria@unm.edu \\ Barbara C. Bogan \\ University of New Mexico
}

Follow this and additional works at: https://digitalcommons.unl.edu/parasitologyfacpubs

Part of the Parasitology Commons

Grover, Jill J.; Duszynski, Donald W.; and Bogan, Barbara C., "Histochemistry of the Tissue Capsule Surrounding Intradermal Mites, Hannemania spp. (Acarina: Trombiculidae) in New Mexico Amphibians" (1975). Faculty Publications from the Harold W. Manter Laboratory of Parasitology. 120.

https://digitalcommons.unl.edu/parasitologyfacpubs/120

This Article is brought to you for free and open access by the Parasitology, Harold W. Manter Laboratory of at DigitalCommons@University of Nebraska - Lincoln. It has been accepted for inclusion in Faculty Publications from the Harold W. Manter Laboratory of Parasitology by an authorized administrator of DigitalCommons@University of Nebraska - Lincoln. 


\section{Histochemistry of the Tissue Capsule Surrounding Intradermal Mites, Hannemania spp. (Acarina: Trombiculidae) in New Mexico Amphibians}

The first occurrence of larval intradermal mites, Hannemania spp., from New Mexico amphibians was recently reported (Duszynski and Jones, 1973, Int. J. Parasit. 3: 531-538). These parasites are always encapsulated by host connective tissue in the dermis of their host and the capsules are grossly visible below the epidermis. Basic histochemical procedures were used to help characterize and give us a better understanding of the structure and formation of this tissue capsule.

Infested skin was removed from live animals which had been pithed and pieces were either fresh-frozen in an Ames Lab Tek cryostat $(-20 \mathrm{C})$ or chemically fixed in Bouin's fixative, FAA, 10\% aqueous (v/v) acrolein (Duszynski and Jones, loc. cit.), or freeze-substituted in absolute ethanol after fixation in liquid nitrogen $\left(\mathrm{N}_{2}\right)$ for $3 \mathrm{~min}$ (ibid.). Tissue fixed in Bouin's and FAA was embedded in 56 to $58 \mathrm{C}$ paraffin and sectioned at 7 to $9 \mu$. Tissues fixed in $10 \%$ acrolein, or in liquid $\mathrm{N}_{2}$, were embedded in a monomer plastic and in paraffin, respectively, and sectioned as reported elsewhere (ibid.). Frozen material, embedded in OCT compound, was sectioned in the cryostat at 7 to $12 \mu$. In addition to routine staining of paraffin-embedded material ( $\mathrm{H} \& \mathrm{E})$, the sectioned material was subjected to the techniques listed in Table I. The usual controls were used in the PAS, lipid, and phosphatase determinations (Humason, loc. cit.). 


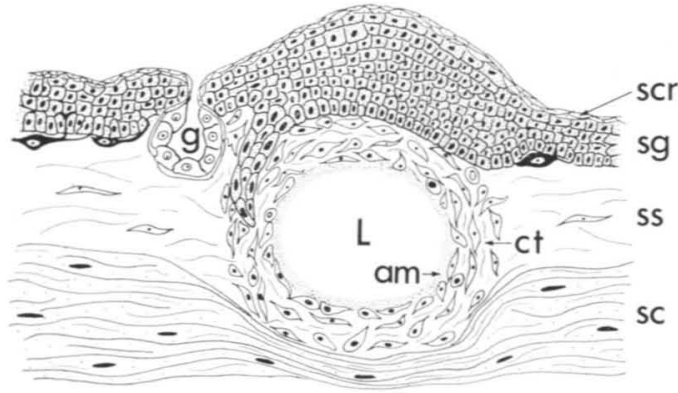

FiguRE 1. Diagram of section of amphibian skin showing tissue capsule formed by the host in response to presence of a Hannemania sp. chigger. Entire capsule located within the stratum spongiosum of the dermis. Note acanthosis of epidermal cells above the capsule, compression and distortion of the stratum compactum directly beneath the capsule, and proliferation of host cell fibroblasts forming outer layer of the capsule. scr $=$ stratum corneum and $\mathrm{sg}=$ stratum germinativum, the 2 layers of the epidermis; ss = stratum spongiosum and $\mathrm{sc}=$ stratum compactum, the 2 layers of the dermis; ct $=$ outer stratum of host connective tissue cells; $a m=$ amorphous, anucleate innermost layer of the capsule; $\mathrm{L}=$ lumen of the capsule where the chigger lives; $\mathrm{g}=\mathrm{a}$ skin gland.

The histology of the skin of various amphibians is similar and the major layers of the dermis and epidermis are illustrated diagrammatically (Fig. 1). Duszynski and Jones (loc. cit.) elaborated on the work of Hyland
(1961, Exp. Parasit. 11: 212-225) and characterized the host-formed tissue capsule within the dermis of B. punctatus infested by Hannemania. Observations on the capsule surrounding these chiggers in other amphibians (A. tigrinum, H. arenicolor, R. pipiens) showed that histologically it is identical in all hosts examined. This capsule consists of two layers (Fig. 1), an outer stratum of host connective tissue cells and an inner, amorphous, noncellular layer which is less well understood, but which is partially characterized here (Table I).

The accumulation of host cell fibroblasts and histiocytes in the outer layer of the capsule is a response on the part of the host to isolate the parasite from host tissue and probably to effect repair function. Tests for carbohydrates, connective tissue, DNA-RNA, and protein were all positive in this layer as would be expected, but lipids could not be demonstrated here. The main reaction product for alkaline phosphatase was found to occur in granular form in the cells of this layer with a reaction in the form of a few granules also associated with the inner layer. Gold and Gould (1951, Arch. Biochem. Biophys. 33: 155) and Washburn (1955, J. Invest. Dermatol. 24: 537544) reported that the concentration of alkaline phosphatase increases as new connective tissue

TABLE I. Staining reactions of the 2 layers of the tissue cyst which surrounds chiggers, Hannemania spp., within the dermis of various amphibians (all techniques are from Humason, 1972, Animal Tissue Techniques, 3rd ed., Freeman, San Francisco, unless cited otherwise).

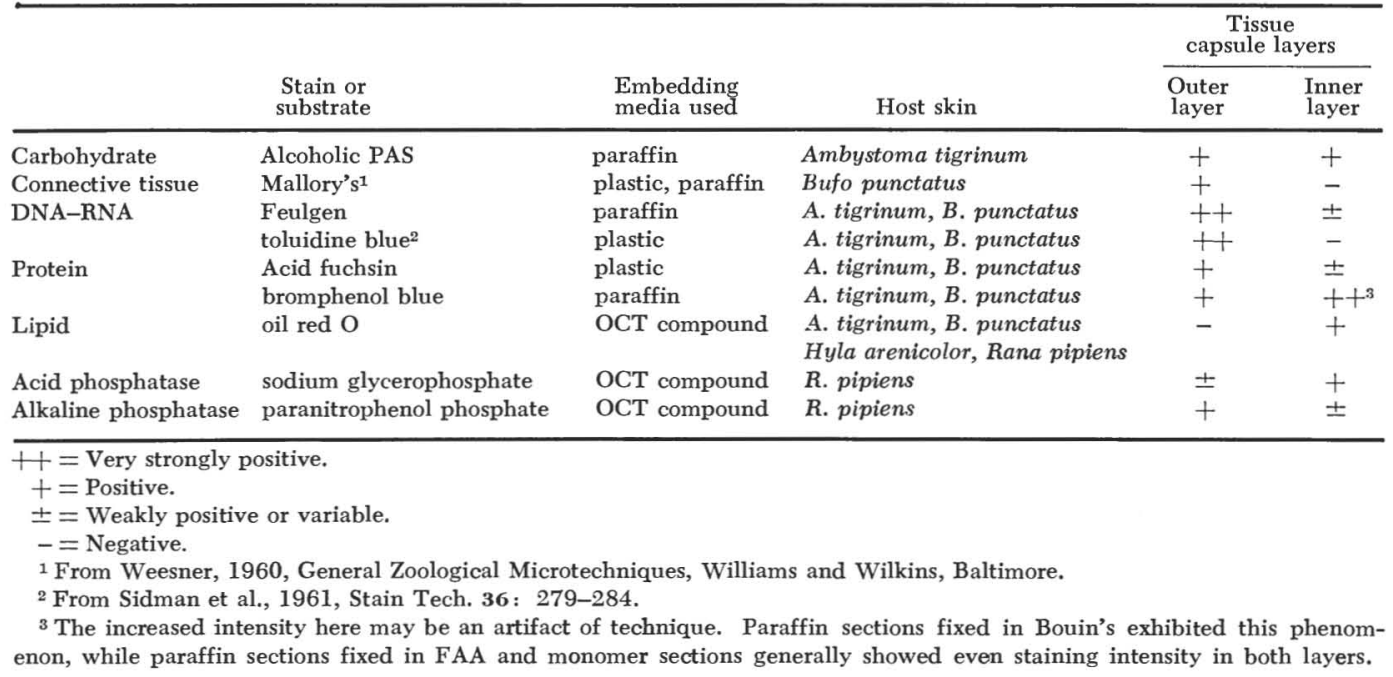


is formed during wound healing in rats. Also, this enzyme is apparently bound by freshly precipitated collagen fibers (ibid.). Acid phosphatase was slightly visualized in this layer and the acellular inner layer gave a very strong reaction for that enzyme. The presence of an acid hydrolase such as acid phosphatase as a marker for lysosomal activity has been reported by de Duve (1963, Ciba Foundation Symposium on Lysosomes, Little and Brown, Boston) and Novikoff (1963, ibid.) and the degeneration of cells due to the action of acid hydrolases is a well-known phenomenon (Brown and Millington, 1968, Histochemie 12: 83-94). This observation plus the striking decrease in DNA-RNA concentration in the innermost capsule layer, i.e., the layer in proximity with the parasite, indicates a general metabolic breakdown of the cells in this area. We can speculate on how this cellular breakdown might occur. Acid phosphatases are membrane-bound and exert no influence on the cell until that membrane is altered. Therefore, some agent is important in the disruption of these membranes and the subsequent release of acid hydrolases. Perhaps the action of parasite metabolites serves as an accessory mechanism in initiating this process. Cryostat-sectioned material stained with oil red $\mathrm{O}$ shows large amounts of lipid in this inner capsule layer. These may be remnants of host cell membrane which are the end products of parasite secretions initiating host cell autolysis through alteration of those lysosomal membranes.

Some of the techniques used in this study were learned while one of us (DWD) was a participant in the National Science Foundation sponsored Short Course on Histochemistry held in the Department of Biology, Vanderbilt University, Nashville, Tennessee, under the direction of Dr. B. J. Bogitsh. His assistance in this regard is sincerely appreciated.

Jill J. Grover, Donald W. Duszynski, and Barbara C. Bogan, Department of Biology, The University of New Mexico, Albuquerque, New Mexico 87131 